\title{
Management of defoliation in Trifolium vesiculosum S. for the production of seeds
}

\author{
[Manejo da desfolha em Trifolium vesiculosum Savi para a produção de sementes] \\ D.F. Araldi ${ }^{1}$, R. Boss ${ }^{1}$, J.M. Machado ${ }^{1}$, D.C. Silveira ${ }^{2 *}$ \\ ${ }^{1}$ Centro de Ciências da Saúde e Agrárias - Universidade de Cruz Alta - Cruz Alta, RS \\ ${ }^{2}$ Universidade Federal do Rio Grande do Sul - Porto Alegre, RS
}

\begin{abstract}
The present study aims to determine the appropriate defoliation management for the production of seeds and forage in arrowleaf clover via trail analysis. The results obtained demonstrated that defoliation practices have a great influence on the composition of seed yield and germination power. In addition, when the goal is the maximum balance between dry matter production and seed yield, this can be achieved in up to two defoliation practices. These results are confirmed by analyzing the positive association between the weight of a thousand seeds and the seed yield. When the third defoliation practice is performed, it negatively correlates with the weight of a thousand seeds, suggesting that, with the increase in defoliation frequency, there is a lower weight of a thousand seeds, and, therefore, lower seed yield. Therefore, management planning in Trifolium vesiculosum Savi that aims at natural reseeding, maximum yield and seed germination must prioritize one to two defoliation practices, aiming to promote favorable conditions for the perennialization of the species. In this context, the trail analysis proved to be a useful tool as a criterion for obtaining the ideal management aiming at the production of seeds and forage in vesicular clover.
\end{abstract}

Keywords: mixed production, annual legume pasture, path analysis, correlation, arrowleaf clover

\section{RESUMO}

O presente estudo visa determinar o manejo de desfolha adequado para a produção de sementes e de forragem em trevo-vesiculoso via análise de trilha. Os resultados obtidos demonstraram que as práticas de desfolha possuem grande influência na composição do rendimento de sementes e no poder germinativo. Além disso, quando o objetivo for o máximo equilíbrio entre a produção de matéria seca e o rendimento de sementes, esse pode ser alcançado em até duas práticas de desfolha. Esses resultados são confirmados ao se analisar a associação positiva entre o peso de mil sementes e o rendimento de sementes. Quando realizada a terceira prática de desfolha, esta se correlaciona negativamente com o peso de mil sementes, sugerindo que, com o aumento da frequência de desfolha, ocorre menor peso de mil sementes e, por conseguinte, menor rendimento de sementes. Portanto, o planejamento do manejo em T. vesiculosum Savi que objetive a ressemeadura natural, o máximo rendimento e a germinação de sementes deve priorizar até duas práticas de desfolha, visando promover condições favoráveis para a perenização da espécie. Nesse contexto, a análise de trilha demonstrou ser uma ferramenta útil como critério para obtenção do manejo ideal visando à produção de sementes e de forragem em trevo-vesiculoso.

Palavras-chave: produção mista, pastagem de leguminosa anual, análise de trilha, correlação, trevovesiculoso

\section{INTRODUCTION}

The introduction of legumes is an alternative to make Integrated Agricultural Production Systems (IAPS) more sustainable (Skonieski et al., 2011).
The genus Trifolium (Fabaceae) includes about 300 species, and some with potential for use in crop rotation systems (Butkute et al., 2014). In addition, they favor the increase of soil fertility,

Recebido em 28 de novembro de 2020

Aceito em 6 de abril de 2021

*Autor para correspondência (corresponding author)

E-mail: diogenessilveira@hotmail.com 
via nitrogen fixation, contributing positively to the production of forage in satisfactory quantity and quality (Ovalle et al., 2010). Among the forage alternatives used in subtropical regions, the arrowleaf clover (Trifolium vesiculosum Savi) stands out, with forage and seed yields superior to the white clover (Trifolium repens Lam), has consolidated use worldwide and in the southern region of Brazil (Snowball et al., 2005), can be used in the form of direct grazing, hay or cover crop. The dormancy of the seeds of this species is around $70 \%$, which allows its perennialization in the area, when well managed (Evans and Mills, 2008; Nori et al., 2019).

It has long been known that forage species have the capacity to adapt to maintain productivity and persistence, resulting from applied management strategies (Davies, 1988). The arrowleaf clover, being a species of erect growth habit, is directly affected in terms of forage production, when subjected to frequent defoliation practices (Ovalle et al., 2010). For this, in many cases, an efficient combination of defoliation and seed production can be achieved, without forgetting that this management practice is carried out, basically, as a support management for more efficient seed production (Ovalle et al., 2010). However, in forage species, where biomass production is the main objective, efforts to increase the efficiency of seed production are still neglected (Martiniello and Silva, 2011).

Understanding agronomic behavior and the associations between characters and / or management are fundamental (Barbosa et al., 2019), especially when looking for the best agronomic performance in terms of seed productivity. Pearson's simple linear correlation is a statistical tool that allows good results to be achieved, guiding which character or management becomes more appropriate (Szareski et al., 2018). When management is highly correlated with seed production, interrelationships must be analyzed, detailing more clearly the determinant effects of the main dependent variable (seed production). Therefore, the path analysis allows the implementation of the correlation coefficient in a cause-and-effect relationship between the variables (Cruz and Carneiro, 2003). The present study aims to determine the proper management of defoliation for the production of seeds and forage in arrowleaf clover by means of correlations and path analysis.

\section{MATERIAL AND METHODS}

The experiment was conducted at the University of Cruz Alta (UNICRUZ), located in the municipality of Cruz Alta / RS, Brazil (28 ${ }^{\circ}$ $33^{\prime} 47.09 " \mathrm{~S}$ and $\left.53^{\circ} 37^{\prime} 22.49^{\prime \prime} \mathrm{O}\right)$, in the period from April from 2015 to January 2016. Climate, according to Köppen's classification, is humid subtropical. The rainfall and temperature exclusion data that occurred and the historical average for the last 20 years were collected by INMET (Figure 1). The soil in the area is classified as a Dystrophic Red Latosol (Oxisol), fertilized and corrected according to the technical recommendations for the crop (Santos et al., 2018). The soil samples from the study site were collected from $0-20 \mathrm{~cm}$ depth and have the following chemical characteristics: clay $=52 \%$; $\mathrm{pH}\left(\mathrm{H}_{2} \mathrm{O}\right)=5.5 ; \mathrm{SMP}$ index $=6.0 ; \mathrm{P}\left(\mathrm{mg} \mathrm{dm}^{-3}\right)=$ 14.6; $\mathrm{K}\left(\mathrm{mg} \mathrm{dm}^{-3}\right)=174 ; \mathrm{O} . \mathrm{M}=3.1 \%$. The experimental design used was randomized blocks, with five replications and four treatments, totaling twenty plots. The species evaluated was the arrowleaf clover (Trifolium vesiculum Savi) cultivar Yuchi.

The treatments consisted of one, two and three defoliation practices, the treatment with only seed production was considered as the standard treatment. The field management was carried out obeying the canopy height of $25 \mathrm{~cm}$, and residue height of $10 \mathrm{~cm}$. Sowing took place on $04 / 17 / 2015$, using a density of $8 \mathrm{~kg} / \mathrm{ha}$ of pure, viable and non-hard seeds. The seeds were inoculated with specific Rizhobium and pelleted with limestone filler. Sampling was carried out at two representative points per plot, using a $0.25 \mathrm{~m}^{2}$ metallic frame. After the evaluations, the plots were subjected to $10 \mathrm{~cm}$ height uniformity. 


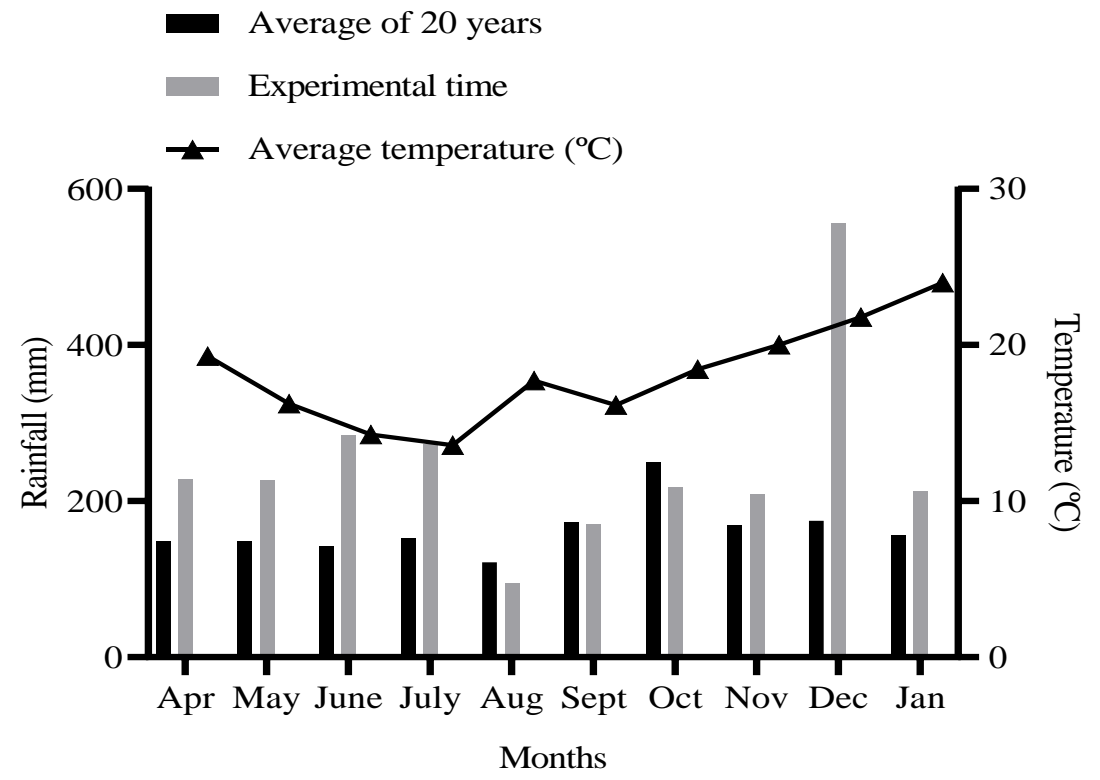

Figure 1. Stratified accumulated rainfall and temperature for the months of the experiment and the historical average over the last 20 years.

The evaluations for forage production were carried out on 07/16/2015, 08/13/2015 and $09 / 29 / 2015$, according to the defoliation management criteria adopted. The collected material was allocated in a forced air oven at $60^{\circ} \mathrm{C}$ for 72 hours to quantify the total dry matter production (TDMP, $\mathrm{kg} / \mathrm{ha}$ ). The harvest of seeds occurred in three moments due to defoliation practices, 12/15/15 (exclusive for seed production and one defoliation practice), 01/07 (two defoliation practices) and 01/14/16 (three defoliation practices). With the aid of a $1 \mathrm{~m}^{2}$ metal frame, collections of the plants were carried out at two representative points of each plot. In one of these samples, the mechanical path was performed and the estimated seed yield (SY, $\mathrm{kg} / \mathrm{ha}$ ). In the other sample, the number of inflorescences per plant (NINFL, inflorescences/plant) was obtained by counting the total inflorescences harvested in $1 \mathrm{~m}^{2}$, divided by the number of plants found in the same area.

The weight of a thousand seeds (WTS, g) was obtained through eight sub-samples of one hundred seeds and weighed on a precision scale $( \pm 0.01 \mathrm{~g})$, according to the methodology described in the Rules for Seed Analysis -RAS (Brazil, 2009). Germination (GER, \%) was obtained through repetitions of 50 seeds for each sample, placed on a "germitest" paper substrate, previously moistened with distilled water, using 2.5 times the dry paper mass, and maintained at $25^{\circ} \mathrm{C}$, in a germination chamber. The final count was performed on the tenth day after sowing, according to Brazil (2009). The data were subjected to analysis of variance (ANOVA) and the $\mathrm{F}$ test. In cases of significant differences, the Tukey test was applied at $5 \%$ probability of error for comparisons between the means. The normality and homogeneity of data variances were verified by the Shapiro-Wilk and Bartlett tests, respectively. The data that did not show normality were transformed by the Box and Cox procedure. For that, the forage production variables were submitted to logarithmic transformation and the other variables to linear transformation.

Correlation coefficients between variables were estimated, whose significance was assessed by Student's t test, at 1 and $5 \%$ probability. The magnitudes of the coefficients of correlation were classified according to Silveira et al. (2021), where $r=0$ was considered null; $r=0$ to 0.30 was considered weak; $r=0.30$ to 0.60 was considered average; $r=0.60$ to 0.90 was considered strong; $r$ $=0.90$ to 1 was considered very strong and $r=1$ was considered perfect. To graphically express the functional relationship of the correlation estimates between the characteristics, a 
correlation network was used, in which the proximity between the features was proportional to the absolute value between their correlations. The thickness of the edges was controlled by applying a cut-off value of 0.40 , which meant that only $\geq 0.40$ had their edges highlighted. Finally, the positive correlations were represented in blue, while the negative correlations were represented in red.

Then, the diagnosis of multicollinearity was made through the analysis of the condition number (NC), which represents the ratio between the highest and lowest eigenvalue of the correlation matrix, based on Montgomery and Peck (1981), if $\mathrm{NC}<100$, collinearity is considered weak, if 100 $<\mathrm{NC}<1.000$, collinearity is considered moderate to strong, in the case of $\mathrm{NC}>1.000$, collinearity is considered severe. Having verified multicollinearity, the path analysis was carried out under multicollinearity, with all the variables studied. The path analysis considered the seed yield (SY) with basic variable (main dependent) and defoliation practices, weight of a thousand seeds and number of inflorescences as explanatory variables. In the second path analysis, the germination variable (GER) was considered as the basic variable (main dependent) and defoliation practices as the explanatory ones. For data analysis, the statistical program GENES (Cruz, 2016) was used.

\section{RESULTS AND DISCUSSION}

The summary of the analysis of variance is shown in Table 1. It appears that there was a significant difference for five of the seven variables evaluated, which reveals variability between treatments. The variation coefficients ranged from 1.18 to $10.25 \%$. There was a significant difference between defoliation practices for total dry matter production (TDMP), number of inflorescences (NINFL) and seed yield (SY) $(\mathrm{P}<0.05)$ (Table 2). The highest and lowest TDMP were obtained when three and one defoliation practice were performed, respectively. On the other hand, TDMP was intermediate when two defoliation practices were performed. The highest TDMP allowed $69.8 \%$ and $48.9 \%$ higher increments when compared to performing one and two defoliation practices, respectively (Table 2 ).

Table 1. Summary of the analysis of variance indicating the variation factors, degrees of freedom (DF) and average squares for the variables evaluated in the experiment

\begin{tabular}{|c|c|c|c|c|c|}
\hline \multirow{2}{*}{ Variation sources } & \multirow{2}{*}{$\mathrm{DF}$} & \multicolumn{4}{|c|}{ Medium square } \\
\hline & & TDMP1 & TDMP2 & TDMP3 & SY \\
\hline Block & 4 & 0.0239 & 0.0153 & 0.0026 & 0.3829 \\
\hline Treatment & 3 & $14.1138 * *$ & $18.0293 * *$ & $16.0026 * *$ & $4.2618 *$ \\
\hline Residue & 12 & 0.0119 & 0.0053 & 0.0026 & 0.2668 \\
\hline Average & - & 1787.90 & 1002.65 & 964.05 & 213.70 \\
\hline P-value & - & 0.000028 & 0.000001 & 0.000001 & 0.026580 \\
\hline SD & - & 1.50 & 1.69 & 1.59 & 0.96 \\
\hline $\mathrm{CV}(\%)$ & - & 4.32 & 4.43 & 5.66 & 10.25 \\
\hline \multirow{2}{*}{ Variation sources } & \multirow{2}{*}{ GL } & \multicolumn{4}{|c|}{ Medium square } \\
\hline & & WTS & & & GER \\
\hline Block & 4 & 0.0019 & & & 0.0148 \\
\hline Treatment & 3 & $0.0094^{\mathrm{ns}}$ & & & $0.0710^{\mathrm{ns}}$ \\
\hline Residue & 12 & 0.0009 & & & 0.0287 \\
\hline Average & - & 11.80 & & & 25.00 \\
\hline $\mathrm{P}$-value & - & 0.000103 & & & 0.125950 \\
\hline SD & - & 0.05 & & & 0.18 \\
\hline $\mathrm{CV}(\%)$ & - & 1.18 & & & 5.28 \\
\hline
\end{tabular}

$*$ and $* *$ significant at 5 and $1 \%$ probability, respectively, by the $\mathrm{F}$ test.

ns: not significant. TDMP1: total dry matter production (1 cut); TDMP2: total dry matter production (2 cuts); TDMP3: total dry matter production (3 cuts); SY: seed yield; WTS: weight of a thousand seeds; NINFL: number of inflorescences; GER: germination; SD: standard deviation; CV: coefficient of variation. 
The production potential is defined by the genetics of the forage plant, while the management adopted is responsible for the expression of this characteristic (Corsi and Santos, 1995), consequently impacting the production of dry matter. In this context, when the purpose is only forage production, management practices are suggested that allow the maximization of pasture use, mainly with the intensification of defoliation practices. The highest NINFL were obtained when the arrowleaf clover culture was managed exclusively for seed production or when a defoliation practice was performed (Table 2). However, a positive correlation between the variables NINFL and SY was expected, which was not verified in the present study (Figure 2). In red clover (Trifolium pratense Lam) and white clover (Trifolium repens Lam) positive correlations were obtained between these variables (Montardo et al., 2003; Lopes and Frank, 2009). However, in the case of species that have high perennialization due to seed dormancy, attention should be paid to management aiming to balance the system to meet the production of forage and seeds. When three defoliation practices were performed (TDMP3), SY was $80.2 \%$ lower than the management that gave priority exclusively to seed production (Table 2).

When two defoliation practices were performed (TDMP2), the maximum SY associated with intermediate TDMP was obtained, providing a balance in the exploration of variables (Table 2). Since, the increase in defoliation practices reduces production and affects the quality of seeds in forages (Coimbra and Nakagawa, 2006). Studies show that performing up to two defoliation practices does not seriously affect the production of seeds in vesicular clover (Ovalle et al., 2010). As it is a species that presents high perennialization due to seed dormancy, attention must be paid to handling aiming the balance of the system to meet the mixed production of forage and seeds (Carambula, 1981).

Table 2. Forage and seed production in Trifolium vesiculosum Savi under different leafing practices

\begin{tabular}{lcccc}
\hline \multirow{2}{*}{ Variables } & \multicolumn{4}{c}{ Defoliation practices } \\
\cline { 2 - 5 } & Zero & One & Two & Three \\
\hline TDMP & - & $2502.0 \mathrm{c}$ & $4236.0 \mathrm{~b}$ & $8280.0 \mathrm{a}$ \\
NINFL & $1307.6 \mathrm{a}$ & $1826.8 \mathrm{a}$ & $373.4 \mathrm{~b}$ & $205 \mathrm{~b}$ \\
SY & $231.4 \mathrm{ab}$ & $289.0 \mathrm{a}$ & $288.6 \mathrm{a}$ & $45.8 \mathrm{~b}$ \\
WTS & $12.0^{\mathrm{ns}}$ & 12.2 & 12.0 & 11.0 \\
\hline
\end{tabular}

* TDMP: total dry matter production (kg / ha). * NINFL: number of inflorescences (inflorescences / plant). * SY: seed yield (kg / ha). *WTS: weight of a thousand seeds (g).

Regarding the WTS variable, there was no significant difference in defoliation management practices ( $\mathrm{P}>0.05)$. Among the evaluated characters, only two: TDMP3 $(-0.97 *)$ and WTS $(0.98 *)$ showed significant phenotypic correlation coefficients at $5 \%$ probability of error with seed yield (SY) (Figure 2). The results demonstrate that, for each defoliation performed, the plant needs to use resources for the recovery of the photosynthetic apparatus, therefore, this energy expenditure results in lower seed yield (Awad et al., 2013). In addition, the TDMP2 variable was negatively correlated with NINFL ( $\mathrm{r}$ $=-0.96 *)$. The character NINFL is pointed out by Montardo et al. (2003) and Lopes and Frank (2009) as one of the characters of importance for seed yield in red and white clover. Based on the results obtained, the use of defoliation management practices should be better studied when the objective is to obtain greater natural reseeding.

In relation to management, when the criterion of three defoliation practices (TDMP3) was adopted, a negative correlation was obtained with the WTS $(\mathrm{r}=-0.98 *)$ and SY $(\mathrm{r}=-0.97 *)$, proving that the intensification of use of the crop for the purpose of forage harvest causes a reduction in these characters (Figure 2). Regarding the intermediate defoliation practice (TDMP2), there was no significant correlation with the WTS and SY. In addition, it is worth mentioning that the maximum SY associated with intermediate TDMP was obtained, providing a balance in the exploration of variables (Table 2). 


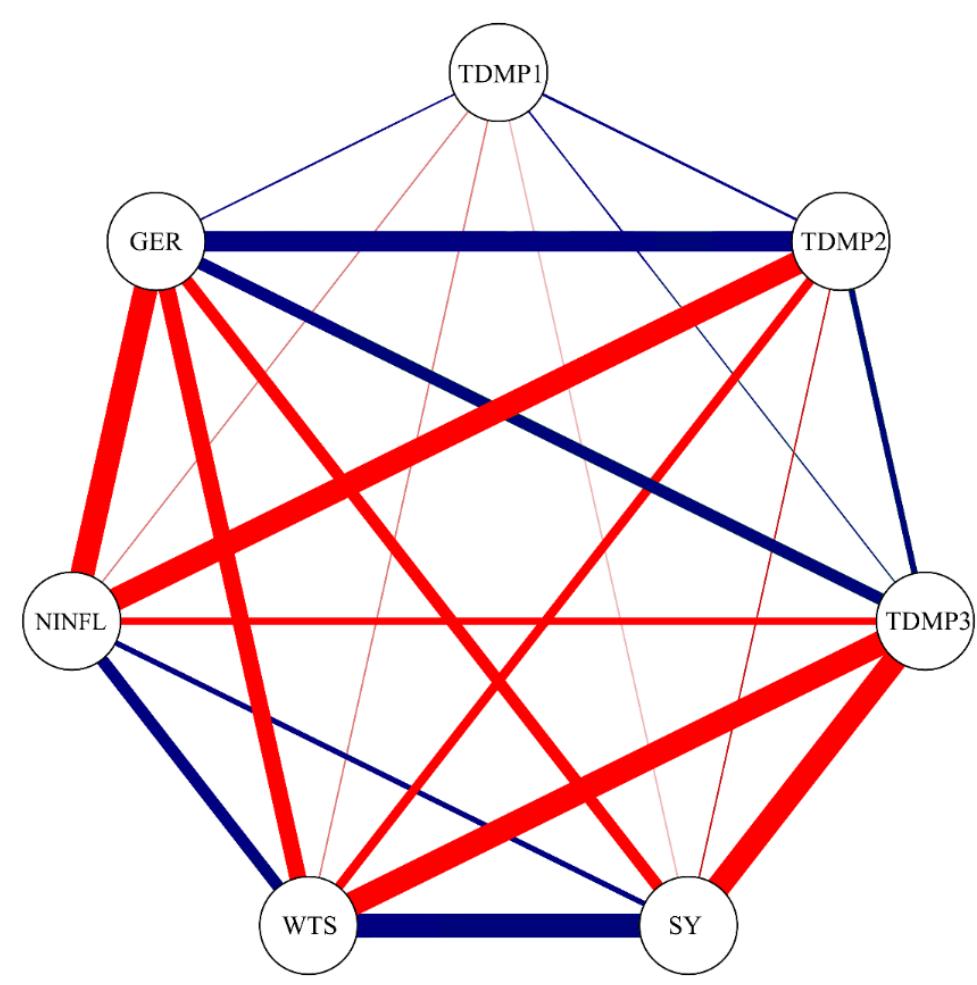

Figure 2. Correlations network o between agronomic traits of arrowleaf clover (Trifolium vesiculum Savi) submitted to different defoliation practices. TDMP1: total dry matter production (1 cut); TDMP2: total dry matter production ( 2 cuts); TDMP3: total dry matter production (3 cuts); SY: seed yield; WTS: weight of a thousand seeds; NINFL: number of inflorescences; GER: germination.

As the phenotypic correlation coefficients do not inform about the true cause and effect relationships between the explanatory variables and the main one (Vieira et al., 2007), the diagnosis of multicollinearity and the path analysis were carried out. Estimates of the direct effects of the independent variables on the seed yield variable (SY) showed that the WTS was the one that showed the greatest direct effect $(0.98)$ on the SY (Table 3), whose estimate was equal to the phenotypic correlation coefficient (Figure 2). Once both coefficients have shown high values and have positive signs, this situation allows the establishment of the hypothesis of a true association between these variables.

TDMP1 showed low correlation and direct effect with SY, showing that this management practice, for seed yield, has little influence on the culture of arrowleaf clover. TDMP2, in turn, presented a negative correlation (-0.49) and a direct positive effect (0.42). In this case, the indirect effects are responsible for the lack of correlation, being these indirect causal factors (WTS). TDMP3 also proved to be influenced by the indirect variable WTS, since it revealed a high correlation $(-0.97)$ and low direct effect $(-0.15)$. The phenotypic estimates of cause and effect, in the path analysis, proved to be reliable due to the high value obtained in the coefficient of determination $\left(\mathrm{R}^{2}=\right.$ 0.99 ) and low residual effects $(0.01)$. It can be verified by the coefficient of determination $\left(\mathrm{R}^{2}\right)$ that the variables explained $99.9 \%$ of the variation in the yield of arrowleaf clover seeds (Table3). All variables had a greater direct effect than the residual effect.

When considering seed germination (GER) as the main dependent variable, the estimates of direct effects showed that TDMP2 was the management practice that revealed the greatest direct effect (Table 4) and correlation coefficient (Figure 2). This situation allows the establishment of the hypothesis of a true association between these variables. The third defoliation practice (TDMP3) indicated a high correlation coefficient and low direct effect, due to the indirect effect of TDMP2. The phenotypic estimates of cause and effect in 
path analysis, proved to be reliable due to the high value obtained in the coefficient of determination $\left(\mathrm{R}^{2}=0.90\right)$ and low residual effects $(0.10)$. It can be seen by the coefficient of determination $\left(\mathrm{R}^{2}\right)$ that the variables explained $90.0 \%$ of the variation in the germination of arrowleaf clover seeds (Table 4). TDMP2 and TDMP3 had a greater direct effect than the residual effect.

Table 3. Estimates of direct and indirect effects, which involved the main variable dependent on seed yield (SY) and the independent explanatory variables on arrowleaf clover (Trifolium vesiculum Savi)

\begin{tabular}{|c|c|c|c|c|c|}
\hline \multicolumn{6}{|c|}{ Main variable seed yield } \\
\hline Item & TDMP1 & TDMP2 & TDMP3 & WTS & NINFL \\
\hline $\begin{array}{l}\text { Direct effect on the main } \\
\text { variable }\end{array}$ & 0.01 & 0.42 & -0.15 & 0.98 & 0.18 \\
\hline Indirect effect via TDMP1 & - & 0.00 & 0.00 & 0.00 & 0.00 \\
\hline Indirect effect via TDMP2 & 0.22 & - & 0.25 & -0.28 & -0.40 \\
\hline Indirect effect via TDMP3 & -0.06 & -0.09 & - & 0.15 & 0.09 \\
\hline Indirect effect via WTS & -0.26 & -0.65 & -0.96 & - & 0.70 \\
\hline Indirect effect via NINFL & -0.05 & -0.18 & -0.11 & 0.13 & - \\
\hline Total $=\mathrm{r}$ & -0.14 & -0.49 & -0.97 & 0.98 & 0.58 \\
\hline Determination coefficient & \multicolumn{5}{|c|}{0.99} \\
\hline Effect of residual variable & \multicolumn{5}{|c|}{0.01} \\
\hline
\end{tabular}

TDMP1: total dry matter production (1 cut); TDMP2: total dry matter production (2 cuts); TDMP3: total dry matter production (3 cuts); SY: seed yield; WTS: weight of a thousand seeds; NINFL: number of inflorescences; GER: germination.

Table 4. Estimates of direct and indirect effects, which involved the main germination-dependent variable (GER) and the independent explanatory variables in arrowleaf clover (Trifolium vesiculum Savi)

\begin{tabular}{lccc}
\hline & Main variable germination & & \\
\hline Item & TDMP1 & TDMP2 & TDMP3 \\
\hline Direct effect on the main variable & -0.35 & 0.78 & 0.35 \\
Indirect effect via TDMP1 & - & -0.18 & -0.13 \\
Indirect effect via TDMP2 & 0.42 & - & 0.47 \\
Indirect effect via TDMP3 & 0.13 & 0.21 & - \\
\hline Total = r & 0.15 & 0.89 & 0.73 \\
\hline Determination coefficient & & 0.90 & \\
K value used in the analysis & & 0.10 & \\
Effect of residual variable & & 0.32 & \\
\hline
\end{tabular}

TDMP1: total dry matter production (1 cut); TDMP2: total dry matter production (2 cuts); TDMP3: total dry matter production ( 3 cuts).

The results allow to affirm that the defoliation practices have great importance in the composition of the seed yield and their germinative power, in arrowleaf clover. Regarding the maximum balance between TDMP and SY, the results showed that it can be achieved in up to two defoliation practices. These results are conclusive when analyzing the positive correlation coefficient between WTS and SY, suggesting that the greater the weight of a thousand seeds, the greater the seed yield. And that the third defoliation practice (TDMP3) correlates negatively with the WTS, suggesting that, with the increase in defoliation frequency, it provides less weight of a thousand seeds, and therefore, lower seed yield. Therefore, management planning in arrowleaf clover that aims at natural reseeding, maximum yield and seed germination must prioritize one to two defoliation practices, aiming to promote favorable conditions for the perennialization of the species.

The results of the correlation analysis (Figure 2) and the path analysis (Table 3 ) were very similar and point to the WTS as the main variable to influence SY. Thus, demonstrating the path analysis as an important tool, as it decomposes the correlation analysis into direct and indirect effects, which makes it safer to list the characteristics and / or managements that should 
be explored, more appropriate to achieve the final objective, in this case, mixed production between seed production and forage.

\section{CONCLUSION}

The integration of seed and forage production requires knowledge of basic and essential aspects, and great precision in handling aiming at seed production in order not to affect the production of this component. Seed production is strongly influenced by the weight of a thousand seeds, and the practice of intense defoliation has a strong negative association with this component. Therefore, this defoliation practice is not recommended for mixed use. The path analysis proved to be a useful tool as a criterion for obtaining the ideal defoliation management aiming at the mixed production of seeds and forage in arrowleaf clover.

\section{REFERENCES}

AWAD, A.; HAFIZ, S.; HAMMADA, M.S. et al. Gran yield production of Sudan grass (Sorghum sudanense (Piper) Stapf) as influenced by cutting numbers, potassium rates, and intrarow spacing in a semiarid environment. Turk J. Agric. Forestry, v.37, p.657-664, 2013.

BARBOSA, M.H.; CARVALHO, I.R.; SZARESKI, V.J. et al. Path analysis and canonical variables of intervarietal maize hybrids. Plant Omics, v.12, p.1-8, 2019.

BRASIL. Ministério da Agricultura e Reforma Agrária. Regras para análise de sementes. Brasília: Mapa/ACS, 2009. 398p.

BUTKUTE், B.; LEMEŽIENĖ, N.; DABKEVIČIENĖ, G. et al. Source of variation of isoflavone concentrations in perennial clover species. Pharmacogn Mag., v.10, p.S181, 2014.

CARAMBUlA, M. Producción de semillas de plantas forrajeras. Montevideo: Hemisferio Sur, 1981. 520p.

COIMBRA, R.D.A.; NAKAGAWA, J. Época de semeadura, regimes de corte, produção e qualidade de sementes de milheto. Rev. Bras. Sementes, v.28, p.21-28, 2006.
CORSI, M.; SANTOS, P.M. Potencial de produção do Panicum maximum. In: SIMPÓSIO SOBRE MANEJO DE PASTAGENS, 12., 1995, Piracicaba. Anais... Piracicaba: FEALQ, 1995. p.275-303.

CRUZ, C.D. Genes Software - extended and integrated with the R, Matlab and Selegen. Acta Sci. Agron., v.38, p.547-552, 2016.

CRUZ, C.D.; CARNEIRO, P.C.S. Modelos biométricos aplicado ao melhoramento genético. 2.ed. Viçosa, MG: Publishing Company of the UFV, 2003. 356p.

DAVIES, A. The regrowth of grass swards. In: JONES, M.B.; LAZENBY, A. (Eds.). The grass crop: the physiological basis of production. New York: Chapman and Hall, 1988. p.85-127.

EVANS, P.M.; MILLS, A. Arrowleaf clover: potential for dryland farming systems in New Zealand. Proc. N. Z. Grassl. Assoc., v.70, p.239243, 2008.

LOPES, R.R.; FRANK, L.B. Análise de trilha dos componentes do rendimento de sementes de trevo-branco. Rev. Bras. Zootec., v.38, p.18651869, 2009.

MARTINIELLO, P.; SILVA, J.A.T. Physiological and bioagronomical aspects involved in growth and yield componentes of cultivated forage species in Medditerranean environments: a review. Eur. J. Plant Sci. Biotech., v.5, p.64-68, 2011.

MONTARDO, D.P.; DALLAGNOL, M.; CRUSIUS, A.F. et al. Análise de trilha para rendimento de sementes em trevo vermelho (Trifolium pratense L.). Rev. Bras. Zootec., v.32, p.1076-1082, 2003.

MONTGOMERY, D.C.; PECK, E.A. Introduction to linear regression analysis. New York: John Wiley, 1981. 504p.

NORI, H.; MOOT, D.J.; MILLS, A. Seed production, seedling regeneration and hard seeds breakdown of annual clovers. N.Z. J. Agric. Res., v.62, p.316-331, 2019.

OVALLE, C.; DEL POZO, A.; FERNÁNDEZ, F. et al. Arrowleaf clover (Trifolium vesiculosum Savi): a new species of annual legumes for high rainfall areas of the Mediterranean climate zone of Chile. Chile J. Agric. Res., v.70, p.170-177, 2010. 
SANTOS, H.G.; JACOMINE, P.K.T.; ANJOS, L.H.C. et al. (2018). Sistema brasileiro de classificação de solos. 5.ed. rev. ampl. Brasília, DF: Embrapa, 2018. 356p.

SILVEIRA, D.C.; PELISSONI, M.; BUZATTO, C. R. et al. Anatomical traits and structural components of peduncle associated with lodging in Avena sativa L. Agron. Res., v.1, p.250-264, 2021.

SKONIESKI, F.R.; VIÉGAS, J.; BERMUDES, R.F. et al. Botanic and structural composition and nutritional value on intercropped ryegrass pastures. Rev. Bras. Zootec., v.40, p.550-556, 2011.
SNOWBALL, R.; WILEY, T.; REVELL, C (2005). Cefalu arrowleaf clover. Farmnote. Department of Agriculture $\mathrm{n}^{\circ}$ 38. 4 p. State of Western Australia, South Perth, Western Australia, Australia.

SZARESKI, V.J.; CARVALHO, I.R.; KEHL, K. et al. Interrelations of characters and multivariate analysis in corn. J. Agric. Sci., v.10, p.187, 2018.

VIEIRA, E.A.; CARVALHO, F.I.F.; OLIVEIRA, A.C. et al. Análise de trilha entre os componentes primários e secundários do rendimento de grãos em trigo. Rev. Bras. Agroc., v.13, p.169-174, 2007. 